\title{
sciendo
}

\section{QUALITATIVE-QUANTITATIVE ANALYSIS OF THE „CIPLARA“ PURSE SEINE CATCHES IN THE ADRIATIC SEA}

\author{
Barbara Zorica $^{1^{*}}$, Vanja Čikeš Keč${ }^{1}$, Vedran Vuletinn ${ }^{1}$, Marin Mihanović ${ }^{2}$ \\ ${ }^{1}$ Institute of Oceanography and Fisheries, Šetalište I. Meštrovića 63, 21000 Split, Croatia \\ ${ }^{2}$ Ministry of Agriculture, Directorate of Fisheries, Alexandera von Humboldta 4b, 10000 Zagreb, Croatia \\ *Corresponding Author, Email: zorica@izor.hr
}

\section{ARTICLE INFO}

Received: 28 May 2020

Accepted: 18 August 2020

\section{Keywords:}

Purse seine

Chelon ramada

Chelon auratus

Oblada melanura

Sarpa salpa

Adriatic Sea

\section{ABSTRACT}

Pelagic fisheries in the area of the eastern part of the Adriatic Sea, more precisely in the Croatian fishing grounds, are one of the most important types of fisheries in Croatia. In this paper, the quantitative and qualitative structure of catches obtained by the "ciplara" purse seine in the Croatian part of the Adriatic Sea was analysed between 2013 and 2018. According to the data collected, the largest catches by this fishing gear were made in the coastal area, precisely in the fishing zones/sub-zones A/A4, E/E2, F/F2, C/C4 and G/G1. 70\% of the catches consisted of targeted species, which indicates that the studied „ciplara" purse seine is a selective fishing gear. Biological analyses are given for four target species.

Zorica, B., Čikeš Keč, V., Vuletin, V., Mihanović, M. (2020): Qualitativequantitative analysis of the "ciplara" purse seine catches in the Adriatic sea. Croatian Journal of Fisheries, 78, 165-172. DOI: 10.2478/cjf-20200016.

\section{INTRODUCTION}

Croatian fishery is well developed and represents one of the most important branches of the economy. According to the values of total catches realized in the segment of marine fishery, it is obvious that one of the most important types of fishing in the Adriatic Sea is pelagic fisheries. Namely, the average proportion of purse seiner catches (except for the tuna purse seiners) in the total Croatian catches between 2012 and 2018 was 91\% (CBS, 2020). The largest catches were obtained by the "srdelara" purse seine, with a share of $99 \%$ in the total catches of the purse seiners. Other purse seiners that are actively used in the Adriatic Sea are as follows: "ciplara", "palamidara", "igličara", "lokardara" and "oližnica". These so-called "small purse seiners", as their name implies ("ciplara" refers to mullets, "palmidara" to Atlantic bonito, "igličara" to garfish, "lokardara" to chub mackerel and "oližnica" to big-scale sand smelt), differ in terms of the target species they catch, and according to their construction and technical characteristics.

Within this study commercial catches of the "ciplara" purse seine, with an average portion in the total catches obtained by "small purse seiners" between 2013 and 2018 (CBS, 2018), were analysed. In general, the "ciplara" purse seine is primarily targeting mullets (Muglidae) and its minimal mesh size is $52 \mathrm{~mm}$. As per legal regulations (Official Gazette of the Republic of Croatia, 2018), in the catches of the "ciplara" purse seine besides mullets (Thinlip grey mullet Chelon ramada (Risso, 1827); golden 
grey mullet Chelon auratus (Risso, 1827)), the following species can be caught: salema Sarpa salpa (Linnaeus, 1758), saddled seabream Oblada melanura (Linnaeus, 1758), European barracuda Sphyraena sphyraena (Linnaeus, 1758), bluefish Pomatomus saltatrix (Linnaeus, 1766), Atlantic bonito Sarda sarda (Bloch, 1793) and little tunny Euthynus allettereatus (Rafinesque, 1810). Fishing ban for this purse seiner is from 1 to 30 November. Generally, the "ciplara" purse seine operates in a way that aggregated school of target fishes formed in the water column is surrounded and caught. In Croatia, this purse seiner, as well as all other so-called "small purse seiners", are allowed at distances less than $300 \mathrm{~m}$ from the coastline, regardless of the sea depth, which means that these fishing gears are excepted from some general provisions of the Mediterranean Regulation (EC, 2006).

The aim of this study was the qualitative and quantitative analysis of commercial catches of the "ciplara" purse seine obtained in the Adriatic Sea, precisely in the Croatian fishing grounds. Furthermore, basic biological parameters of some target species were determined to establish whether this fishing gear caught species and whether it was used according to the law.

\section{MATERIALS AND METHODS}

The qualitative and quantitative analysis of commercial catches of "ciplara" obtained from 2013 until the end of 2018 was done based on the official data of the Ministry of Agriculture, the Directorate of Fisheries. Quantitative official data in the observed period were analysed by year, fishing zone and sub-zone.

Biological samples of commercial catches of "ciplara" were collected within the framework of the Croatian Data Collection (DCF) in the area of Croatian fishing grounds between January 2017 and December 2019. The samples were collected seasonally either on board a commercial purse seiner or at the landing place during the time of sampling. Overall, 5 onboard and 12 samples at a landing place were collected. A representative sample of commercial catches of "ciplara" consisted of at least 30 specimens of each target species that were caught. Collected biological samples were adequately stored and immediately transported to the Institute of Oceanography and Fisheries, Split, Croatia.

Total length (TL) $( \pm 0.1 \mathrm{~mm})$ and total body weight $(W)$ $( \pm 0.01 \mathrm{~g})$ of each sampled specimen were measured in the laboratory. Length frequency analysis was done by species. Sex of each specimen was assessed macroscopically. Overall sex ratio $(\mathrm{m} / \mathrm{f})$ by species was examined. The length-weight relationship of each sampled species was calculated applying the exponential regression $\mathrm{W}=\mathrm{aTL} \mathrm{L}^{\mathrm{b}}$, where $\mathrm{W}=$ total fish weight in $\mathrm{g}$; $\mathrm{TL}=$ total length in $\mathrm{cm}$; $\mathrm{a}=$ proportionality constant; and $\mathrm{b}=$ allometric growth parameter. The hypothesis of isometrical growth was tested using Student's t-test $(\mathrm{P}<0.05)$.

\section{RESULTS AND DISCUSSION}

During the investigated period (2013 - 2018), annual commercial catches obtained by the "ciplara" purse seine varied from $23556.1 \mathrm{~kg}$ (2013) to $36478.3 \mathrm{~kg}$ (2017), while their average value in those six years was 29658 $\pm 4794.7 \mathrm{~kg}$. Those catches were exclusively realized in the area of fishing zones A, C, E, F and G (Fig. 1). Although the quantities of catches made by "ciplara" in each fishing zone fluctuated during the observed period (Fig. 2), it was obvious that the largest catches were obtained in the area of the central Adriatic (fishing zones F and G). Considering that in the Republic of Croatia each fishing zone is divided into smaller geographical units, i.e. subzones, the analysis of commercial catches of "ciplara" was also done by the fishing sub-zones A4, E2, F2, C4 and G1 (Fig. 3). Bearing in mind that the "ciplara" purse seine is intended for catching coastal fish species, the observed commercial catches in the mentioned fishing zones/subzones were expected.

Throughout the study period (January 2013 - December 2018), qualitative analysis of the catches pointed out that the share of target species in the total commercial catches of "ciplara" was $70 \%$, while the largest portion belonged to the two mullet species - thinlip grey mullet and golden grey mullet (Fig. 4). The remaining share of the catch (30\%) was by-catch and discarded fish species. Namely, the amount of the discarded fish was only $0.2 \%$ and it comprised salema, saddled seabream, round sardinella and European conger specimens. The number of specimens of by-catch species was somewhat higher in the catches of the "ciplara" purse seine, i.e. their share in the total catch was between $2 \%$ and $10 \%$. Those bycatch species were greater amberjack, gilthead seabream, sardine and anchovy. Qualitative analysis of commercial catches of "ciplara" indicated that the studied fishing gear is actually used for catching the species for which it is intended.

During biological sampling that was carried out between January 2017 and December 2019, specimens of four target species (thinlip grey mullet, golden grey mullet, salema and saddled seabream) were collected by the "ciplara" purse seine along the eastern Adriatic Sea (Table 1). The widest and the narrowest length range was obtained for salema and thinlip grey mullet specimens, respectively (Fig. 5). Female specimens of all investigated species had a slightly higher mean value of total body length and total body weight than males (Table 1). Length frequency distribution of each studied species was mainly in accordance with the previously reported length ranges, not only for the Adriatic (Pallaoro et al., 1998, 2003; Boglione et al., 2006; Sinovčić and Zorica, 2006; Glamuzina et al., 2007; Kraljević et al., 2011) but also for the area of the Mediterranean (Jadot et al., 2002; Boglione et al., 2006; Crosetti and Blaber, 2016; Jisr et al., 2018). Slight deviations observed within length ranges 


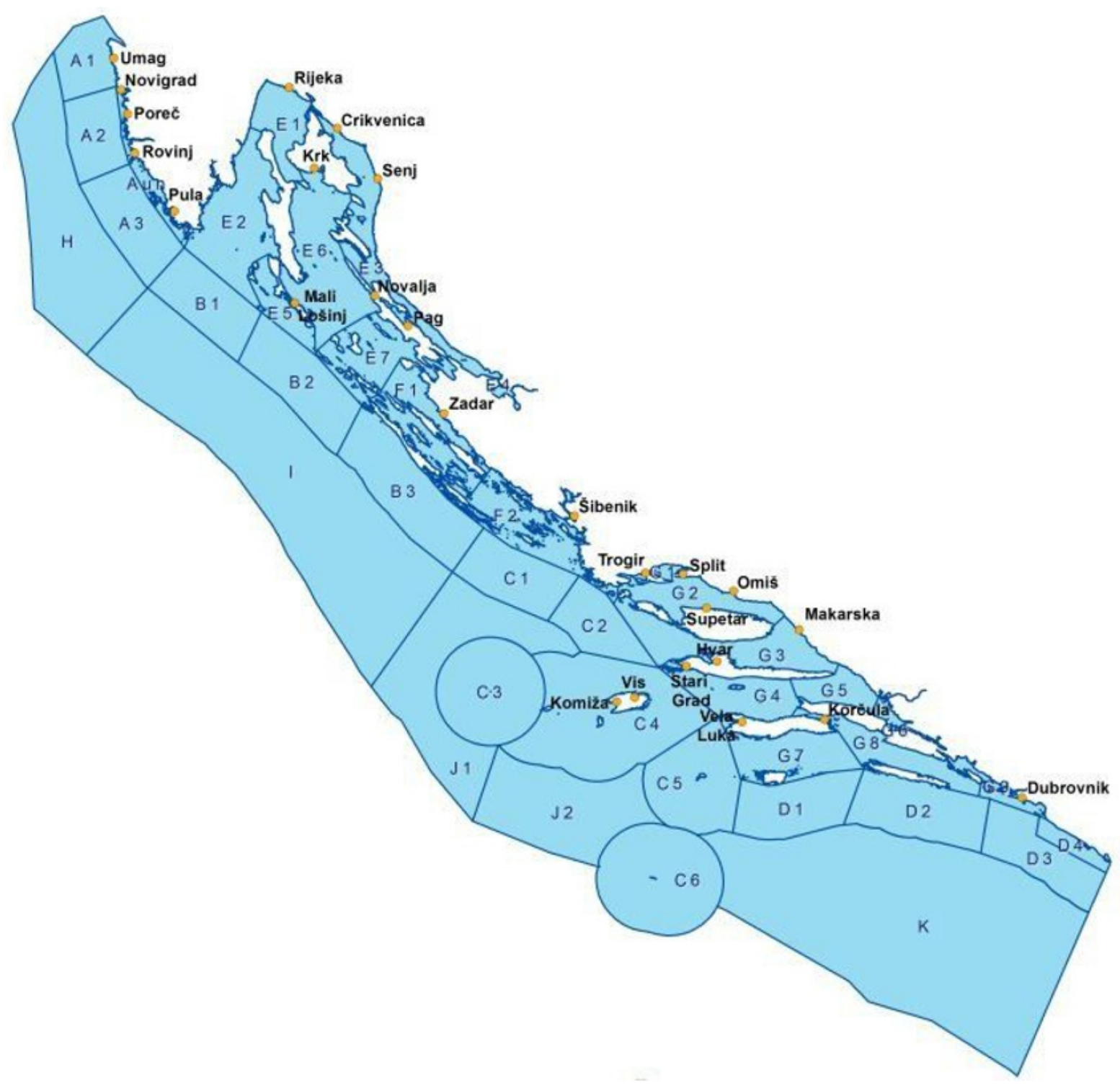

Fig 1. Schematic display of the Croatian fishing grounds with marked fishing zones/sub-zones, https://ribarstvo.mps.hr/

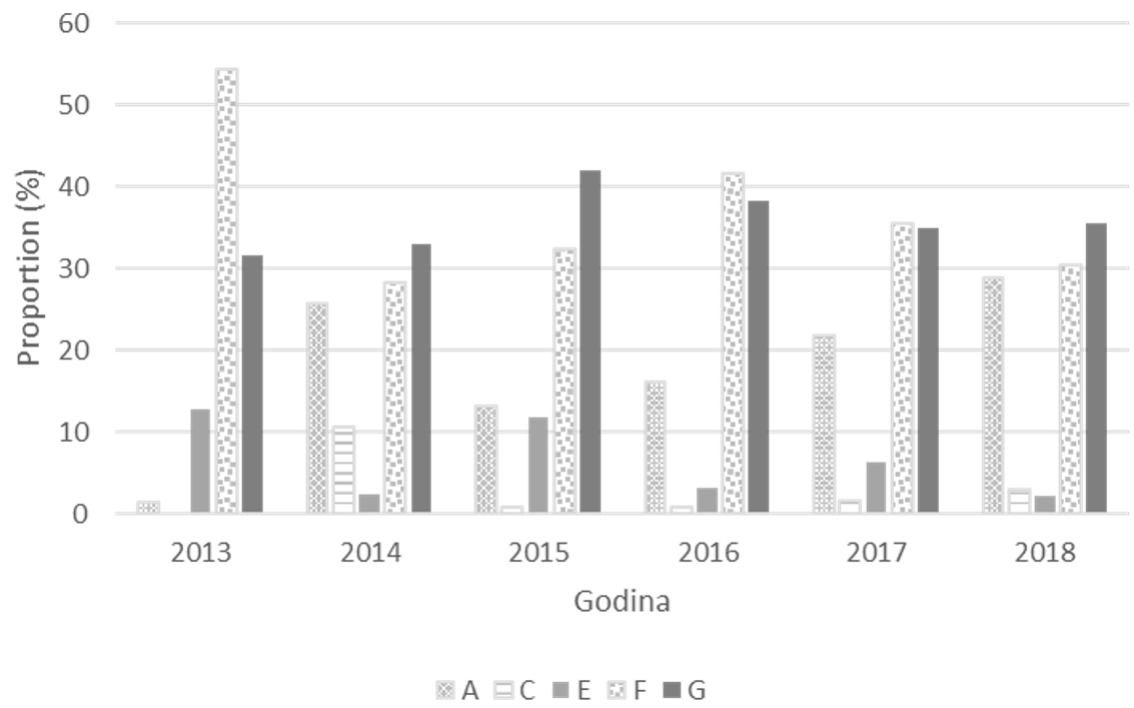

Fig 2. Oscillations of the purse seine annual catches of "ciplara“ realized in the area of fishing zones A, C, E, F and G between January 2013 and December 2018 
Fishing zone A

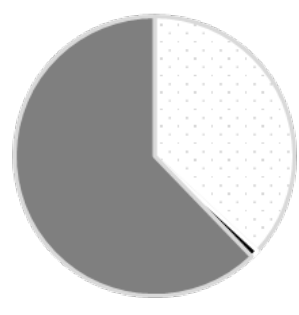

$\square \mathrm{A} 1 \square \mathrm{A} 2 \square \mathrm{A} 4$

Fishing zone C

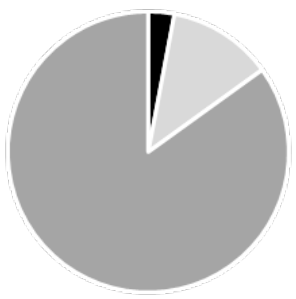

$\square \mathrm{C} 1 \square \mathrm{C} 2 \square \mathrm{C} 4$
Fishing zone $\mathrm{F}$

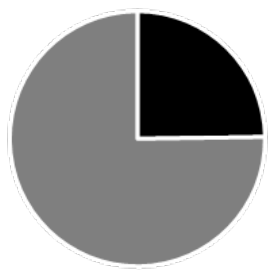

-F1 $\square \mathrm{F} 2$

Fishing zone G

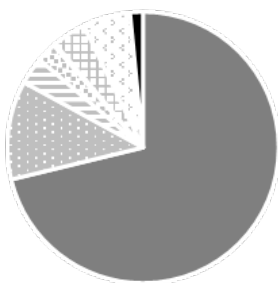

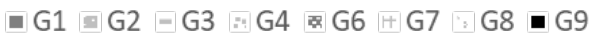

Fishing zone $\mathrm{E}$

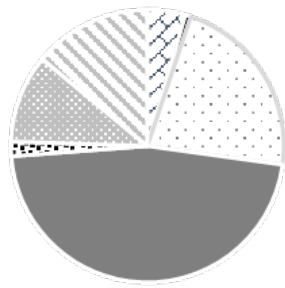

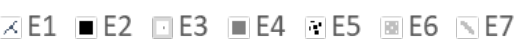

Fig 3. Distribution of purse seine catches of „ciplara“ by sub-zones within each fishing zone, January 2013 - December 2018

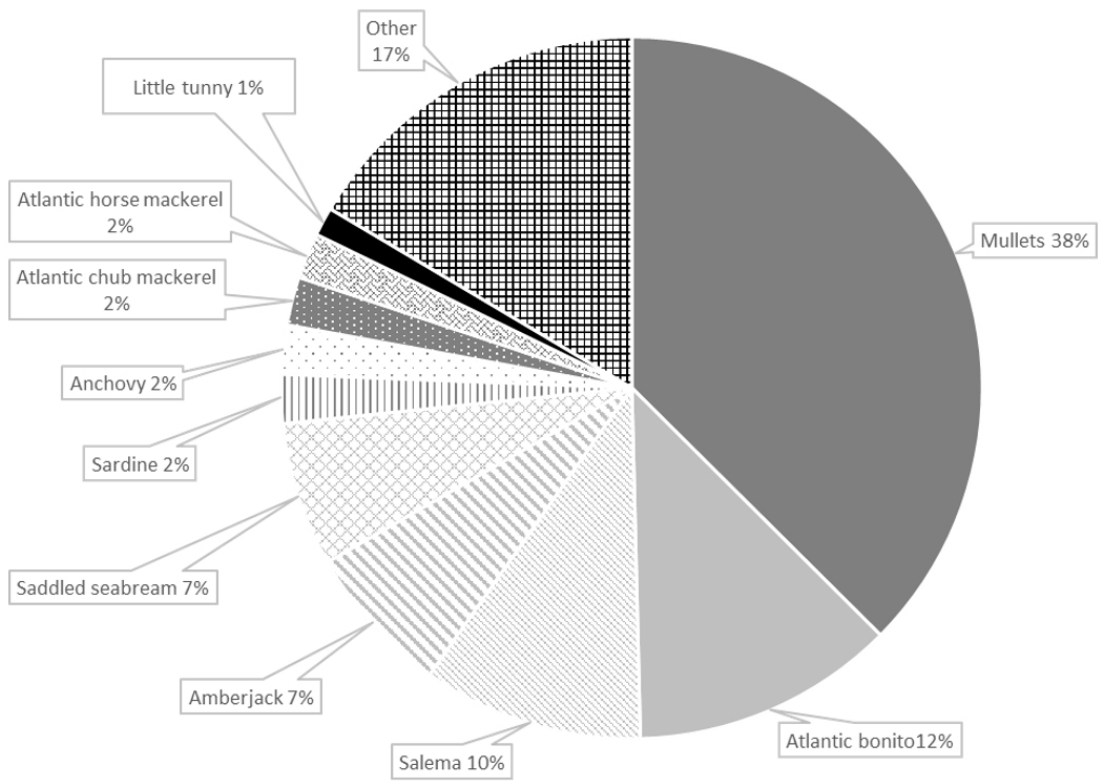

Fig 4. Qualitative analysis of purse seine catches of „ciplara“ realized between January 2013 and December 2018 
Table 1. Review of the number of collected individuals (N), their length (TL) and mass (W) range with the average values for four species collected with the "ciplara“ purse seine in the area of the Eastern Adriatic, January 2017 - December 2019

\begin{tabular}{|c|c|c|c|c|c|c|}
\hline Species & Sex & $\mathrm{N}$ & Range TL (cm) & Mean TL \pm SD $(\mathrm{cm})$ & Range W (g) & Mean $\mathrm{W} \pm \mathrm{SD}(\mathrm{g})$ \\
\hline \multirow[t]{3}{*}{$\begin{array}{l}\text { Thinlip grey mullet } \\
\text { Chealon ramada }\end{array}$} & $\delta$ & 93 & $26.1-37.9$ & $30.0 \pm 2.5$ & $121.91-356.36$ & $199.17 \pm 48.40$ \\
\hline & 우 & 89 & $26.8-37.7$ & $30.6 \pm 2.5$ & $136.12-414.56$ & $210.06 \pm 52.78$ \\
\hline & total & 182 & $26.1-37.9$ & $30.5 \pm 2.4$ & $121.91-414.56$ & $204.49 \pm 50.61$ \\
\hline \multirow[t]{3}{*}{$\begin{array}{l}\text { Golden grey mullet } \\
\text { Chealon aurata }\end{array}$} & 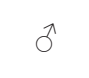 & 45 & $26.0-32.6$ & $30.0 \pm 1.4$ & $159.34-283.75$ & $220.41 \pm 28.73$ \\
\hline & 우 & 84 & $26.1-34.8$ & $30.8 \pm 1.8$ & $165.35-331.71$ & $240.03 \pm 35.23$ \\
\hline & total & 129 & $26.0-34.8$ & $30.5 \pm 1.7$ & $159.34-331.71$ & $233.18 \pm 34.17$ \\
\hline \multirow[t]{3}{*}{ Salema Sarpa salpa } & 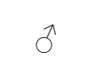 & 58 & $18.4-30.0$ & $23.3 \pm 2.7$ & $86.4-384.28$ & $184.72 \pm 64.88$ \\
\hline & q & 138 & $22.6-33.6$ & $27.6 \pm 2.5$ & $170.49-520.59$ & $298.35 \pm 80.92$ \\
\hline & total & 182 & $18.4-33.6$ & $26.3 \pm 3.2$ & $86.40-520.59$ & $264.01 \pm 92.22$ \\
\hline \multirow[t]{3}{*}{$\begin{array}{l}\text { Saddled seabream } \\
\text { Oblada melanura }\end{array}$} & 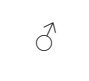 & 55 & $19.1-29.9$ & $22.7 \pm 1.7$ & $105.56-239.3$ & $149.67 \pm 33.78$ \\
\hline & q & 127 & $19.7-29.8$ & $23.8 \pm 1.7$ & $98.37-430.04$ & $172.61 \pm 46.36$ \\
\hline & total & 196 & $19.1-29.9$ & $23.5 \pm 1.8$ & $98.37-430.04$ & $165.82 \pm 44.09$ \\
\hline
\end{tabular}

were mainly related to different sampling techniques (different fishing gear; scientific papers related to the Adriatic Sea area were sampled with trawl nets) or to the fact that sampling was performed in an ecologically different area (the Mediterranean Sea). The length of all collected specimens was above the value of the minimum legal length size (minimal legal length size is given only for two mullet species ( $T L>16.0 \mathrm{~cm}$ ), while for salema and saddled seabream, this length is not defined). Sex ratio analysis pointed out that this ratio was uniform only for thinlip grey mullet population $(\mathrm{m} / \mathrm{f}=0.51 ; \chi 2=0.088$, $d f=1, \quad P>0.05$ ), while in other investigated species predomination of females was established (golden grey mullet $\mathrm{m} / \mathrm{f}=0,35, \quad \chi 2=11.194, \quad \mathrm{df}=1, \quad \mathrm{P}<0.05 ;$ saddled seabream $m / f=0.30, \chi 2=32.653, d f=1, P<0.05$; salema $m /$ $f=0.30, \chi 2=28.485, d f=1, P<0.05)$. In general, the sex ratio in a population is a key demographic parameter, and the uniform sex ratio $(m / f=1)$, established only for thinlip grey mullet population in this study, is the only evolutionarily stable strategy (Hamilton, 1967). From an ecological point of view, a female-biased sex ratio, which throughout this study was stated for populations of golden grey mullet, saddled seabream and salema, is certainly more desirable because the reproductive potential of a fish species is determined by the number of matured females and their capacity to produce viable eggs and larvae (Murua et al., 2003).

The length-weight relationship for each studied species is shown in Fig. 6. Although allometric coefficient values (b) for all collected species were below $3(2.09<b<2.87)$, their values were not statistically different from $3(0.30<$ $t<0.84 ; N>125 ; P>0.05)$. Hence, all the species covered within this study had isometric growth (specimens increase their total body length and weight proportionally as they grow). Reviewing the previously published values of the allometric coefficient for the studied species in both the Adriatic and Mediterranean Sea, some slight oscillations can be noticed but they were most likely related to the number of analysed specimens, their length range, sampling area and time (before, during or after spawning). Overall, in the area of the Adriatic allometric coefficient of thinlip grey mullet varied from 2.69 to 3.18 (Dulčić and Kraljević, 1996; Dulčić and Glamuzina, 2006; Sinovčić and Zorica, 2006; Glamuzina et al., 2007); for golden grey mullet it varied from 2.704 to 3.068 (Dulčić and Kraljević, 1996; Dulčić and Glamuzina, 2006; Kraljević et al., 2011); for saddled seabream it oscillated from 3.017 to 3.123 (Pallaoro et al., 1998) and salema allometric coefficient varied between 3.126 and 3.265 (Dulčić and Kraljević, 1996; Dulčić and Glamuzina, 2006). The ranges of the above mentioned allometric coefficients also correspond to their values obtained for the same species distributed along the Mediterranean (Jadot et al., 2002; Koutrakis and Tsikliras, 2003; Boglione et al., 2006; Karakulak et al., 2006; Ceyhan et al., 2008; Moreno-Valcárcel et al., 2012; Crec'hriou et al., 2013; Moutopoulos et al., 2013; Bayhan and Kara, 2015; Crosetti and Blaber, 2016; Jisr et al., 2018). 
(a)

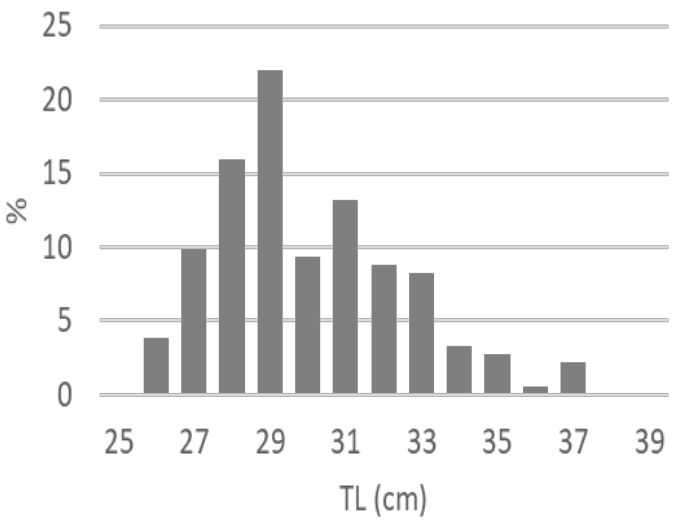

(b)

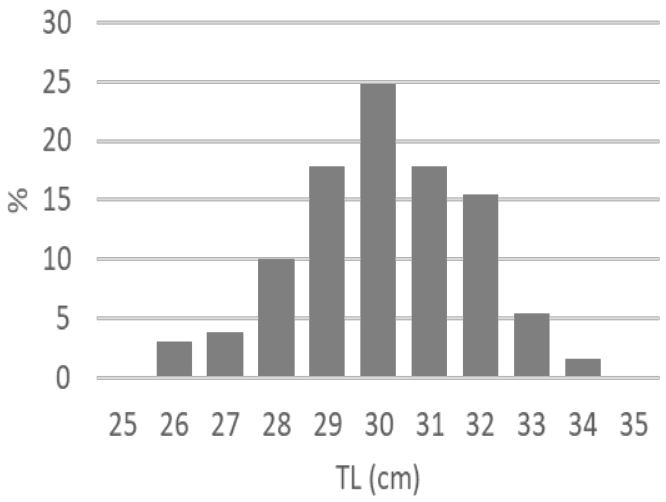

(c)

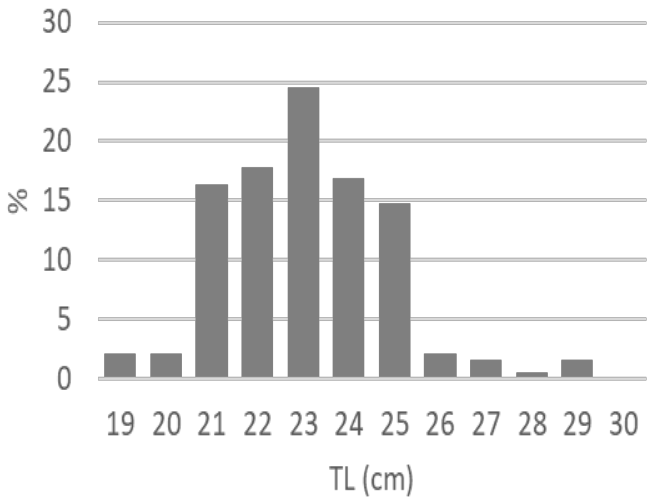

(d)

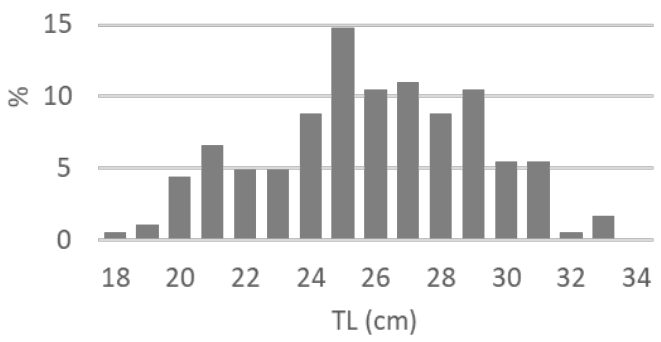

Fig 5. Length frequency distribution of thinlip grey mullet (a), golden grey mullet (b), saddled seabream (c) and salema (d) collected in the area of eastern Adriatic, January 2017 - December 2019 (a)

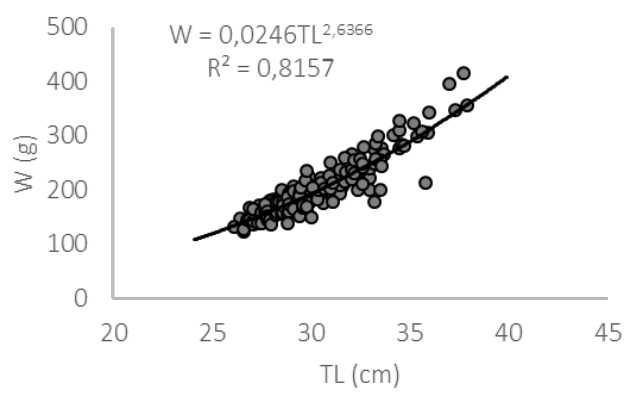

(b)

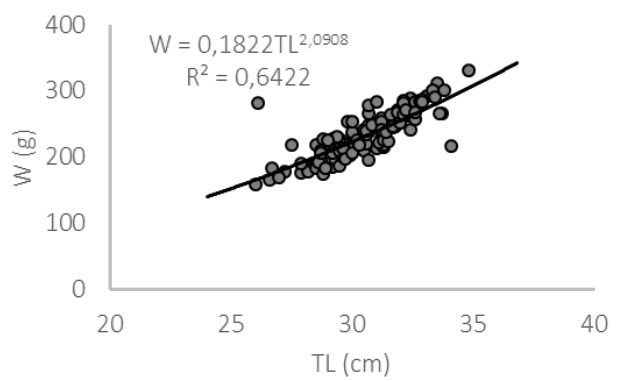

(c)
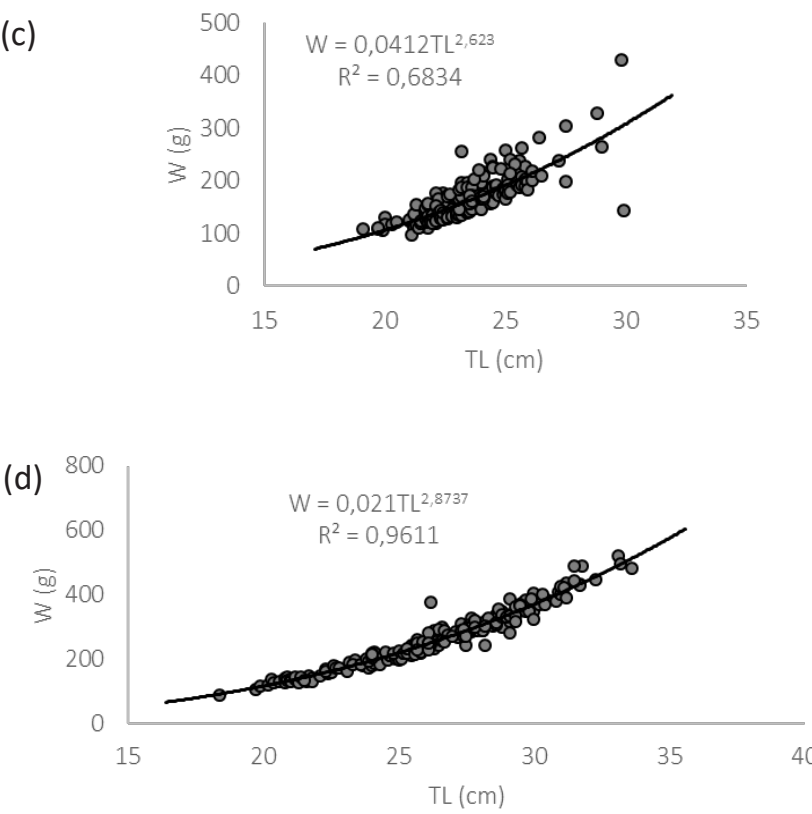

Fig 6. Length-weight relationship of thinlip grey mullet (a), golden grey mullet (b), saddled seabream (c) and salema (d) collected in the area of the Eastern Adriatic, January 2017 - December 2019

\section{ACKNOWLEDGEMENTS}

This study was supported by the Ministry of Agriculture of the Republic of Croatia, as a part of the research project "Data Collection Framework (DCF)". Referees' comments and suggestions are greatly appreciated. 


\section{SAŽETAK}

\section{KVALITATIVNO-KVANTITATIVNA ANALIZA LOVI- NA OSTVARENIH OKRUŽUJUĆOM MREŽOM - PLIVARICOM "CIPLAROM“ U JADRANSKOM MORU}

Plivaričarski tip ribolova na području istočnog dijela Jadranskog mora točnije u hrvatskom ribolovnom moru ima iznimni značaj. U sklopu ovog rada analizirana je kvantitativna i kvalitativna struktura lovina ostvarenih plivaricom "ciplarom“ u razdoblju od 2013. do 2018. godine na području ribolovnog mora $\mathrm{RH}$. Na temelju prikupljenih podataka uočeno je da se najveći ulovi ovim ribolovnim alatom ostvaruju u priobalju odnosno u ribolovnim zonama/podzonama A/A4, E/E2, F/F2, C/ C4 i G/G1. 70\% ulova ostvarenih ovim ribolovnim alatom čine ciljane vrste što upućuje da je istraživana ribolovna mreža selektivna. Od ciljanih vrsta detaljnije su analizirane jedinke cipla balavca, cipla zlatara, ušate i salpe.

Ključne riječi: plivarica, Chelon ramada, Chelon auratus, Oblada melanura, Sarpa salpa, Jadran

\section{LITERATURA}

Bayhan, B., Kara, A. (2015): Length-weight and lengthlength relationships of the Salema Sarpa salpa (Linnaeus, 1758) in İzmir Bay (Aegean Sea of Turkey). Pakistan Journal of Zoology, 47, 1141-1146.

Boglione, C., Costa, C., Giganti, M., Cecchetti, M., Dato, P.D., Scardi, M., Cataudella, S. (2006): Biological monitoring of wild thicklip grey mullet (Chelon labrosus), golden grey mullet (Liza aurata), thinlip mullet (Liza ramada) and flathead mullet (Mugil cephalus) (Pisces: Mugilidae) from different Adriatic sites: meristic counts and skeletal anomalies. Ecological Indicators, 6, 712-732.

CBS (2018): Croatian Bureau of Statistics, (available at: https://www.dzs.hr/default_e.htm (accessed 14 April 2020).

CBS (2020): Croatian Bureau of Statistics, (available at: https://www.dzs.hr/Hrv_Eng/publication/2020/01-0401_01_2020.htm (accessed 12 February 2020).

Ceyhan, T., Akyol, O., Erdem, M. (2008): Length-Weight Relationships of Fishes from Gökova Bay, Turkey (Aegean Sea). Turkish Journal of Zoology, 33, 69-72.

Crec'hriou, R., Neveu, R., Lenfant, P. (2013): Lengthweight relationship of main commercial fishes from the French Catalan coast. Journal of Applied Ichthyology, 29, 1191-1192.

Crosetti, D., Blaber, S. (2016): Biology, Ecology and Culture of Grey Mullets (Mugilidae). CRC Press. https://doi. org/10.1201/b19927
Dulčić, J., Glamuzina, B. (2006): Length-weight relationships for selected fish species from three eastern Adriatic estuarine systems (Croatia). Journal of Applied Ichthyology, 22, 254-256.

Dulčić, J., Kraljević, M. (1996) Weight-length relationships for 40 fish species in the eastern Adriatic (Croatian waters). Fisheries Research, 28, 243-251.

EC (2006): COUNCIL REGULATION (EC) No 1967/2006 of 21 December 2006. Official Journal of the European Union L 409, 11-85.

Glamuzina, B., Dulčić, J., Conides, A., Bartulović, V., MatićSkoko, S., Papaconstantinou, C. (2007): Some biological parametersof the thin-lipped mullet Liza ramada (Pisces Mugilidae) in the Neretva river delta (Eastern Adriatic, Croatian cost). VIE ET MILIEU, 57, 7-13.

Hamilton, W. D. (1967): Extraordinary sex ratios. A sexratio theory for sex linkage and inbreeding has new implications in cytogenetics and entomology. Science, 156, 477-488.

Jadot, C., Ovidio, M., Voss, J. (2002): Diel activity of Sarpa salpa (Sparidae) by ultrasonic telemetry in a Posidonia oceanica meadow of Corsica (Mediterranean Sea). Aquatic Living Resources, 15, 343-350.

Jisr, N., Younes, G., Sukhn, C., El-Dakdouki, M.H. (2018): Length-weight relationships and relative condition factor of fish inhabiting the marine area of the Eastern Mediterranean city, Tripoli-Lebanon. The Egyptian Journal of Aquatic Research, 44, 299-305.

Karakulak, F., Erk, H., Bilgin, B. (2006): Length-weight relationships for 47 coastal fish species from the northern Aegean Sea, Turkey. Journal of Applied Ichthyology, 22, 274-278.

Koutrakis, E. T., Tsikliras, A. C. (2003): Length-weight relationships of fishes from three northern Aegean estuarine systems (Greece). Journal of Applied Ichthyology, 19, 258-260.

Kraljević, M., Dulčić, J., Pallaoro, A., Matić-Skoko, S. (2011): Age and growth determination of the golden grey mullet, Liza aurata (Risso, 1810) from the Adriatic Sea by using scale readings and length frequency analysis. Acta Adriatica, 52, 223-234.

Moreno-Valcárcel, R., Oliva-Paterna, F. J., Arribas, C., Fernández-Delgado, C. (2012): Length-weight relationships for 13 fish species collected in the Doñana marshlands (Guadalquivir estuary, SW Spain). Journal of Applied Ichthyology, 28, 663-664.

Moutopoulos, D. K., Ramfos, A., Mouka, A., Katselis, G. (2013): Length-Weight Relations of 34 Fish Species Caught by Small-Scale Fishery in Korinthiakos Gulf (Central Greece). Acta Ichthyologica Et Piscatoria, 43, 57-64.

Murua, H., Kraus, G., Saborido-Rey, F., Witthames, P. R., Thorsen, A., Junquera, S. (2003): Procedures to Estimate Fecundity of marine Fish Species in Relation to their Reproductive Strategy. Journal of Northwest Atlantic Fishery Science, 33, 33-54. 
Official Gazette of the Republic of Croatia (2018): Pravilnik o obavljanju gospodarskog ribolova na moru okružujućim mrežama plivaricom palamidarom, plivaricom ciplaricom, plivaricom lokardarom, plivaricom igličarom i plivaricom oližnicom. Narodne novine, 2018.

Pallaoro, A., Cetinić, P., Dulčić, J., Jardas, I., Kraljević, M. (1998): Biological parameters of the saddlead bream Oblada melanura in the eastern Adriatic. Fisheries Research, 38, 199-205.
Pallaoro, A., Šantić, M., Jardas, I. (2003): Feeding habits of the saddled bream, Oblada melanura (Sparidae), in the Adriatic Sea. Cybium, 27, 261-268.

Sinovčić, G., Zorica, B. (2006): Population dynamics and preliminary results on stock assessment of grey mullet, Liza ramada (Risso, 1826) in the Šibenik Bay (Middle Adriatic, Croatia). Periodicum Biologorum, 108, 169176. 